\title{
ADAMASTOR, GIGANTOMACHIES, AND THE LITERATURE OF EXILE IN CAMÕES' LUSÍADS
}

\author{
JOHN HILTON \\ University of KwaZulu-Natal, Durban
}

Canto 5 of Camões' Lusiads tells the celebrated myth of Adamastor. ${ }^{1}$ This section of the poem describes a Portuguese voyage of exploration led by Vasco da Gama in 1497 down the west coast of Africa and around the "Cape of Storms," later renamed the "Cape of Good Hope." The narrative of their journey reveals a Renaissance preoccupation with new knowledge that surpasses (but always acknowledges) that of ancient writers. ${ }^{2}$ Thus, according to the narrator, who is none other than Vasco da Gama himself, the land of Mauretania (the home of the mythological Giant Antaeus) was little known before this voyage (Canto 5, Stanza 4, hereafter cited as 5.4), the island of Madeira was previously known by name only (5.5), and the river Zaire was unheard of in antiquity (5.13). Da Gama also states that he had seen and experienced St. Elmo's fire and waterspouts (5.18-22) phenomena that he claims had never been described before (Canto $5.17,23) .{ }^{3}$ After he had been transformed into a mountain by the victorious gods (5.58-59), Adamastor himself became a promontory unknown to ancient geographers such as Ptolemy, Pomponius Mela, ${ }^{4}$ Strabo, and Pliny (5.50). Finally, the poems of Homer and Virgil were outdone by the epic voyages of the Portuguese $(5.89,94)$-in other words by the Lusiads. Included in this catalogue of the unknown are the local inhabitants of Africa. As the Portuguese pass the Tropic of Capricorn, they land and capture (but later release) one of the inhabitants who appears to them selvagem mais que o bruto Polyphemo, "A savage worse than brutal Polypheme" (5.28, tr. Bacon), who strangely prefers beads to the gold so loved by the Portuguese. ${ }^{5}$ A daring sailor, Velloso, ventures into the interior in search of information about India but is driven 
away by the "Ethiopians" 6 and rescued with difficulty from the ships. When they reach the Cape they are confronted by an apparition of its personification, Adamastor, the demon of the Cape. The Giant resembles the Colossus of Rhodes in size, engages the sailors directly in dialogue and predicts that those who had discovered the Cape would be punished by a storm and shipwreck for their bold daring (the Greek concept of divine punishment following excessive and violent arrogance-hubris-appears to be at work here). The survivors would suffer at the hands of the local inhabitants. Adamastor then identifies himself as one of the "hard sons of Earth,"7 the brother of Enceladus, Aegeon, Briareus, and the others who made war on Jupiter (5.51). ${ }^{8}$ He had joined the revolt out of love for Thetis, the wife of Peleus, whose mother Doris9 tricked Adamastor by leading him to believe that her daughter would be his, but he finds that she continually eludes him by changing shape. When the Titans were defeated by Jupiter, Adamastor was changed into the earthen shape of the Cape promontory, surrounded by the waves of Thetis.

The Adamastor episode has "given the poem its place in world literature" (Quint 114) and has become "the white man's creation myth of Africa" (Gray 15). ${ }^{10}$ Despite this, there is a wide divergence of opinion even on the intertextual and literary character of the passage. Some scholars rather surprisingly consider it to be an entirely original creation, ${ }^{11}$ others trace an elaborate network of intertexts ranging from Homer, to Virgil, Ovid, and beyond. ${ }^{12}$ This article argues that in creating the myth of Adamastor, Camões has endeavoured to synthesise and reshape a wide range of Classical intertexts relating to Giants and gigantomachies into a new paradigm of the unknown. In addition, I hope to show that Camões uses this mythological theme in the subtle and ambiguous manner characteristic of those who write from exile. Gigantomachy myths generally invite an allegorical, political reading and possibly for this reason were so frequently avoided in Classical Latin Literature that they can be considered a significant element in the recusatio theme. ${ }^{13}$ Ovid, for example, avoided the topos in favour of erotic subjects (Am. 2.1.11-16, see Trist. 2.1.71-72). ${ }^{14}$ The struggle of the Giants against the gods was a subject suited to high epic and the grand style of rhetoric just as questions of natural philosophysuch as the origins and nature of the universe-were (Innes 165, quoting Demetrius On Style 75).

In the Renaissance, pagan myths, like pagan mysteries, played an important part in humanistic culture. ${ }^{15}$ The revolutionary myth of Prometheus, for example, that was so shocking to the conventional 
religion of Greece, ${ }^{16}$ was a popular theme for painters and sculptors during this period. ${ }^{17}$ Camões had a detailed knowledge of Classical mythology and used his Classical learning in a purposeful and allegorical way. His poem faced censorship a number of times after its publication, resulting in the temporary excision of the names of gods and goddesses from his narrative. ${ }^{18}$ His youthful dramatization of the story of Seleucus and his son Antiochus' love for his stepmother Stratonike (alluding to the contemplated marriage between John III and his father's widow in 1521), his version of Plautus' Amphitruo, a tragi-comedy in which Jupiter seduces the virtuous Alcumena and cuckolds the eponymous Theban general (see n. 2), the poet's tragically unfulfilled love for a woman of higher station, and his involvement in a street fight, led to his exile from the Portuguese court on two occasions in 1546 and again in 1552 (Nowell 125-126). During his exile, he wrote a poetic paraphrase of Psalm 137, By the Rivers of Babylon, lamenting his banishment (tr. Bacon 409-23). He returned to Lisbon seventeen years later in 1569 where he died in disillusionment in 1580. Given this background it is probable that his treatment of Adamastor would contain within it an ambiguity towards the imperial mission of Portugal that is to be expected in exilic literature. ${ }^{19}$ I therefore argue that the poem should not be considered without qualification or reserve "the national epic of Portugal" or "an epic ... vibrant with patriotic pride." 20 This is not to say that Camões does not express himself patriotically on occasion-against his paraphrase of the epitaph on the tomb of Scipio Africanus on going into exile (ingrata patria, non possidebis ossa mea, "ungrateful fatherland, you will not possess my bones"), ${ }^{21}$ should be set the words of his letter Em fin accaberey à vida, e verràm todos que fuy afeiçoada a minho patria, "I am ending the course of my life, the world will witness how I have loved my country" (quoted by Mickle xxii). The figure of Adamastor in the Lusiads exemplifies the psychological and literary complexity of exilic literature.

Camões' epic models provided him with a wealth of material from which to construct the figure of Adamastor, the avenger of the arrogant presumption of the Portuguese. David Quint (107-25) has analysed the tradition of the "epic curse" in Homer, Virgil, and Camões. He shows how, after being blinded and tricked by Odysseus, the Cyclops Polyphemus prays to his father Poseidon asking that Odysseus may suffer the loss of his comrades before his return to Ithaca and that he would find trouble in his household when he arrives there (Od. 9.528-35). The confrontation between the Giant and Odysseus and his men represents a "failed colonialist 
scenario" (Quint 108) in which Polyphemus is identified with the hostile natural elements that the Greeks must confront and overcome. Homer's narrative portrays the one-eyed Giant as a savage and murderous drunkard who flouts the civilised norms of hospitability normally shown to strangers in the Greek world. ${ }^{22}$ His death is represented as the triumph of human ingenuity, technology, and self-control over the brutish forces of nature. ${ }^{23}$ The story is told also in very similar terms in the Third Voyage of Sindbad the Sailor. ${ }^{24}$ In this case the Giant is for the first time specifically labelled "black," just as Camões envisaged him. ${ }^{25}$ The "epic curse" in this account is reduced to the Giant and his wife shouting threats and swearing at Sindbad and his crew. In both of these versions, the Giants in the story are described living as shepherds in a remote, rural context (Odysseus and his men had been blown off course for nine days [Od. 9.105-107] until they came to the land of the Lotus-Eaters and then to the habitation of the Cyclopes). These one-eyed Giants are alien to the Greeks who descend on their community and disrupt their lives. In fact, the myth reflects a double displacement; in the folklore tradition Polyphemus is generally depicted as a loner who lived outside of human society and the law. ${ }^{26}$ At the same time Odysseus and his men roam the seas in search of a way back to Ithaca.

What the Homer passage does bring to Camões' description of Adamastor are the qualities of savagery and primitivism in the Giant, but also his isolation from his fellow Cyclopses (who abandon him when he cannot identify his assailant) and the remoteness of region in which he lives. The address of Polyphemus to his favourite ram $(\mathrm{Od}$. 9.447-60) well conveys the pathos of the predicament the Giant finds himself in after his blinding. There is undeniably an emotional ambiguity about the way Homer describes Odysseus' treatment of Polyphemus, which could be explained psychoanalytically along the lines that Polyphemus is a fatherfigure, the blinding is a symbolic castration, and the myth belongs to the same type as the Cronus/Zeus conflict. ${ }^{27}$ The Portuguese poet has retained this ambiguity by portraying Adamastor as a failed lover of the sea-goddess Thetis, just as Theocritus describes Polyphemus' unrequited love for Galatea (Idylls 6,11). Camões was probably most familiar with this version of the myth from Virgil (Ecl. 9.39-43; 2.19-27, 7.37-40) and especially Ovid (Met. 13.738897), who portrays the Giant torn between his love for Galatea and his hatred for her younger lover Acis, whom he finally crushes to death with a huge rock from which the blood of the young boy streams and eventually becomes a river. ${ }^{28}$ In Ovid, Galatea hates 
Polyphemus as much as she loved Acis. There is a similar intensity of emotion in the episode in the Lusiads. Here Adamastor is a failed suitor who uses violence to win his way in love. He threatens Doris, the mother of Thetis, with war if he did not win her daughter (5.53-54). Doris gives an evasive reply but when Adamastor attempts to take hold of Thetis, the Giant finds himself turning into stone. Adamastor thus becomes a kind of Prometheus, punished for his audacity in loving an immortal goddess by being stretched out into a mountainous promontory, Tantalus-like forever tormented by the sea that surrounds him. His humanity is linked to that of the Portuguese explorers, his failure resembles that of the Portuguese (Lipking 218). ${ }^{29}$ The story of Adamastor's love for Thetis reduces the otherness of the Giant and brings him closer to the human level; his violence dehumanises him entirely. This shift in characterisation counteracts the initial ominous and daunting description given above (5.39). The theme of Polyphemus in love may originally (in Hellenistic poetry) have been intended satirically, but at the same time he is a pathetic and unhappy figure. ${ }^{30}$ His longing is expressed in the song in which he serenades Galatea (Met. 13.789-869). There is something of this in Camões' Adamastor, who in many ways resembles the exiled poet nursing an unrequited love. However, there is no pastoral context of singing shepherds in Camões; Adamastor and Thetis act out their story in the isolation of the remote Atlantic Ocean.

Homer's Polyphemus story is closely imitated by Virgil (Aen 3.588-691), who relates how Aeneas' Trojans rescue a Greek, Achaemenides, from the Cyclops and his neighbours (compare the account in Ovid Met. 14.160-220 which is more flattering to Aeneas). Achaemenides (whose father was Adamastus) ${ }^{31}$ had been left behind by Odysseus and had been living in the woods in fear of the Giant monsters that inhabited the place. Camões clearly echoes Virgil's description (Aen. 3.658) of the one-eyed Giant (monstrum horrendum, informe, ingens, cui lumen ademptum, "A monster, grisly, misshapen, titanic, his eye gone," tr. C. Day Lewis 1966) in his words monstro horrendo, "horrendous monster" (5.49). As Polyphemus launches an attack against them, Aeneas pities his former Greek enemy and takes him on board his ship. The nullification of national differences between Greek and Trojan is important here. Human friend and foe stand together against the wild forces of nature represented by Polyphemus. In Virgil's account, however, Polyphemus does not curse the Trojans as they escape (he has no particular cause to do so in this case since Aeneas and his men have done him no harm); instead he utters an 
inarticulate roar that causes the sea and far-off Italy to shake in fear (3.671-73). So too in Camões (5.60) when Adamastor recedes com um sonoro / Bramido muito longe o mar soou, "high and higher / a howl sonorous o'er the sea there spread" (tr. Aubertin). In both Virgil and Camões the Giant is a lonely and isolated figure, bereft of the companionship of his own kind. Both Homer and Virgil, therefore, "enrich their characterization" of the Giant "by showing a human, pathetic side of the blinded Giant, racked with pain, seeking consolation in animals." 32

Virgil's narrative has also shaped the Velloso incident in the Lusiads, since in both cases a sailor is rescued from irate local inhabitants. However, it is in the Dido story that Quint locates the continuing tradition of the "epic curse." Abandoned by her lover, Aeneas, the Carthaginian queen calls down on the Trojan leader and his descendants war, death, and humiliation at the hands of her people, even though it is decreed by fate that Aeneas would achieve his aim of founding the future city of Rome (Aen. 4.612-21) - the power that would eventually destroy Carthage. Dido then immolates herself spectacularly on a pyre, recalling the theatrical suicide of another female opponent of Rome, Cleopatra VII of Egypt. In her emotional frenzy at her betrayal, Dido resembles Homer's Cyclops to an extent, even though she retains the sympathy of the reader because of her undeserved death. Virgil's treatment of the story underlines the human cost of empire that is repeatedly demonstrated in the poem. Throughout his narrative, Virgil qualifies Aeneas' task of establishing the city of Rome and its subsequent world dominion. There is another passage in Virgil that could be added to that of Dido's curse- the prophecy of the Sibyl of Cumae to Aeneas (6.83-97). The old priestess of Apollo foretells the sufferings of the Trojans in the wars that they will have to fight in Latium in order to establish the city of Rome. ${ }^{33}$ Significantly, however, Dido, like Aeneas, is an exile, hoping to establish a new city at Carthage. She is cut off from her home city of Tyre, and is vulnerable to the local inhabitants of Africa led by her suitor, Iarbas. Like Cleopatra she is of alien blood.

What the Virgil passages add to the figure of Adamastor therefore is the element of nationalism, more particularly a frustrated nationalism. Camões' Giant is the resolute opponent not of an individual, as Polyphemus is of Odysseus, or Acis, but of the Portuguese nation, and like Dido his vengeance is to be exacted on future expeditions that venture into his waters. At the same time, Adamastor's narrative expresses the pathos of the destruction of these fleets. The curse of Adamastor in the Lusiads explains the fate 
of subsequent Portuguese expeditions, under Cabral (1500), Francesco da Almeida (1510) and, most famously, Manuel de Sousa de Sepulveda (1552), but the story of the death of Donna Leonora da Sá in the words of the Giant invoke pity for these intruders rather than vengeance against them. ${ }^{34}$ Moreover, whereas Dido is betrayed in love by Aeneas, Adamastor's cause is not as easy to define. He explains that the Portuguese explorers are guilty of daring to do what no other nation has done, namely to enter the southern ocean of which he is the protector (5.41) and which the ancient geographers Ptolemy, Pomponius Mela, Strabo, and Pliny, did not know of (5.50). They have penetrated "the hidden secrets of nature" (os segredos escondidos / Da natureza, 5.42) and have transcended the bounds imposed on humanity (ibid.). ${ }^{35}$ As a result, Adamastor swears to take personal revenge against future Portuguese expeditions (5.44). He himself will literally be the tomb of the fleet of da Almeida (in other words it will be lost at sea), whereas the expedition of de Sepulveda will be destroyed by the people of Africa. Unlike Dido, though, Adamastor does not claim that the Africans are his lineal descendants. When challenged, he identifies himself as the previously undiscovered Cape of Storms who had joined the revolt against the gods out of love for Thetis, an affair which Camões has omitted to explain fully. He was perhaps thinking of the prophecy in Aeschylus' Prometheus Bound (757-70) that Thetis would produce a son more powerful than his father. Since Thetis was desired by Zeus in Pindar Isthmian 8 (2657), this could be construed as a revolutionary prophecy. ${ }^{36}$ By expressing his love for Thetis, Adamastor was casting in his lot with the rebels. However, all this has been left unexpressed in the poem and has to be inferred by the reader. Adamastor is, however, deceived by Thetis and her mother, Doris. In grief and shame, the Giant goes $A$ buscar outro mundo, onde não visse / Quem de meu pranto $e$ de meu mal se rise, "To seek some world, with no one at my side, / My mourning and my suffering to deride" (5.57, tr. Aubertin). His fellow Giants are, however, defeated by the gods, and Adamastor is transformed into the Cape as punishment. This personal statement characterises him as an outcast from the known world, dehumanised by his rejection by Thetis and by the failure of his bid for power. The nationalist element in the Adamastor episode therefore conceals a more intimate grievance. The hostility of the spirit of the Cape of Storms does not follow a colonialist or imperialist act of transgression except in hindsight; his rage in the poem stems from personal disappointment. ${ }^{37}$ While Adamastor's love of Thetis makes him more human, the failure of his love turns 
him into a sullen force of nature, rather than a symbol of African retribution. 38

It is this emotional alienation in Adamastor that colonial and post-colonial writers alike have responded to (Lipking 217). Camões' Giant owes much to Hesiod's creation myth (Theogony 107, tr. West), which celebrates "those whom the briny Sea fostered"Chaos, Tartaros, Erebos, and Eros. Hesiod also describes the "proud-hearted" Cyclopic Giants "who gave Zeus his thunderbolt. In other respects they were like the gods, but a single eye lay in the middle of their forehead ... and strength and force and resource were upon their works" (Theogony 139-46, tr. West). Other Giants born of Ge and Ouranos were "mighty and stern, not to be spoken of [literally: 'not named'] ... overbearing children" (Theogony 14753 , tr. West). The primal strength of Adamastor resembles these primitive beings forged in the process of the creation of the world and later condemned to be relegated to Tartaros. ${ }^{39}$ Their lack of names underlines their status as formless and chaotic forces and their lack of individual identity. It is perhaps for this reason that Camões chose the obscure name "Adamastor" for his Titan (see Appendix), despite the fact that Classical mythology provides a large number to choose from (such as Briareus, Enceladus, Prometheus, and others). Adamastor's lack of identity is reflected in his changes of shape. He is a protean figure who appears first as a cloud (5.37), then as a Giant male figure of human form with beard, eyes, hair, mouth, teeth, and voice (5.39-40), an inhuman monster (5.49), the Cape of Storms (5.50), and finally an evansecence once more (5.60).

It is clear therefore that the Adamastor myth should be located particularly in the mythology of Giants and the gigantomachy, and hence in the theme of alienation, exile, and defeat. ${ }^{40}$ This would have been a motif familiar to Camões from medieval chivalrous epic. ${ }^{41}$ Giants feature frequently in Ariosto's Orlando Furioso (for example, the contest between Bradamant and a Giant, 11.11-20, and the inhuman, cannibal Giant Caligorant outwitted by Astolpho, 15.43-62). Ariosto often invokes the names of these creatures, such as Typhoeus and the Laestrygonians, while referring to the Classical gigantomachies $(3.3,33.24,34.38)$. Camões also refers directly to the theme of the battle between gods and Giants, but not always consistently. In the Lusiads Giants sometimes confront and oppose the Portuguese, as when Tethys foretells that the Portuguese, like the chivalrous knights of Ariosto's epic, will meet Giants on their voyages (10.141), and the Moors insult them, not being aware that they are David to their Goliath (3.111). Sometimes, Giants are 
mentioned ecphrastically to foreshadow conflict and disaster, as when, before the storm that almost wrecks the Portuguese fleet on its way to India, Camões describes the mythological scenes depicted in sculptures in the submarine cave of Neptune: the theft of fire from heaven by Prometheus (6.11), the battle of gods against Giants, and the burial of Typhoeus under Mt. Etna (6.13). Sometimes, however, the Portuguese are themselves the Giants confronting the king of heaven. The King of Malindi explicitly compares the daring voyages of the Portuguese with the assault on heaven by the Giants, and the attempted rape of Persephone, wife of Hades by Pirithous and Theseus (2.112). The lightning-bolts that afflict the Portuguese during a storm on their way to India exceed the thunderbolts that Jupiter used against the Titans in the battle that preceded their destruction in the Flood (6.78). Most tellingly, the old man of Belem launches into a scathing denunciation of the voyage of Da Gama as it is departing from Lisbon. His speech relates the acquisitive desire for material wealth to the fall of man through the four ages as described by Ovid (Met. 1.76-162) resulting in a race that was contemptrix superum saevaeque avidissima caedis / et violenta fuit: scires e sanguine natos, "contemptuous of the gods, violent and cruel, with a lust to kill: it was obvious that they were the children of blood" (tr. Innes 1955). Like Prometheus who stole fire from heaven (4.103), the old man argues, Portuguese sinfulness and greed will bring about a disaster, leaving the home country vulnerable to attack by the Moors. Camões, the poet, himself does not escape censure (4.102), since poetry encourages nationalistic ambition and thus abets these delusions of grandeur.

Gigantomachies in Classical mythology often set the forces of chaos against those of order. In Horace Odes 3.4, the battle between Jupiter and the Titans is portrayed as a conflict between brute force directed towards evil ends (vis consili expers, Odes 3.4.65, viris / omne nefas animo moventis, Odes 3.4.67-68) and the controlled use of power (vim temperatam, Odes 3.4.66). In terms of the Civil War this translates into the struggle between Antony and Octavian that the Augustan poet interpreted in cosmological, political, religious, and moral terms (Hardie 88). Virgil uses the theme indirectly in his description of the storm released by Aeolus against the Trojans at the request of Juno (Aen.1.50-156) just as Hesiod associated winds with the children of Typhoeus (see Greek typho:s, typho:n, Eng. "typhoon"). Virgil's description of the battle of Actium between Antony and Octavian also contains echoes of the Gigantomachy (Aen. 8.625-731, esp. 691-692). In this passage the contrast is between the Olympian gods versus the Egyptian pantheon, 
anthropomorphic versus theriomorphic religion, Rome versus the Other. Both passages of the Aeneid are linked by parallel structural elements (Hardie 104-110). Virgil (Aen. 8.184-275) also describes how Hercules killed the Giant Cacus, a murderous cattle-thief, by throttling him to death in his smoky cave and bringing him out into the light for people to see: nequeunt expleri corda tuendo / terribilis oculos, unltum uillosaque saetis / pectora semiferi atque exstinctos faucibus ignis, "Our people could never be done with gazing / At the bestial creature--his terrible eyes, his face, the bristling / Hair on his breast, the extinct volcano of his gullet." (Aen. 8.265-67, tr. Day Lewis). The volcano analogy is clear in this episode (see also the confinement of Enceladus under Mt. Aetna in Sicily in Aen. 3.57882, Hardie 110-18). All these passages feature the throwing or the rupturing of mountains at some point. ${ }^{42}$ Finally, Virgil makes use of the Gigantomachy theme in describing battle scenes at the conclusion of the Aeneid. These include the fight between Aeneas and Aegaeon (Aen. 10.565-70) and Aeneas and Turnus (Aen. 12.887-952).

In the dying years of the Roman Empire as political and military tensions rose, the theme of the war of Giants against gods escalated in importance. The incomplete Gigantomachy in Claudian (Carm. 37) describes how the Giants fight against Zeus in defence of their mother, Ge (the Earth) and her Titan offspring. They are to "conquer heaven" (domitura deos, 12) in revenge for the sufferings of Prometheus and Tityus. They assault the gods and attempt to rape the goddesses (38-41). The battle is cosmological; the aim is control of the world. Eventually, the Giant Porphyrion attempts to tear up the island of Delos to throw it at the sky.

The gigantomachy myth was not restricted to the contesting elites of the Roman Empire, however; it also had a long and complex history in Greek and Jewish thought, ${ }^{43}$ particularly in texts that quite frequently were critical of prevailing social conditions. ${ }^{44}$ Its most remarkable feature is that it records the conflict between Titans/Giants and the gods- $\mathrm{a}$ conflict resulting from the generational struggle between Ouranos and Kronos (an account that Plato wished to be told only to initiates in his ideal state [Rep. 378a]). Hesiod, whose Works and Days describes the harsh conditions under which Greek peasants lived in the Archaic period, describes the conflict of the Titans, such as Iapetos, and his sons Menoitios and Prometheus, against Zeus, who was aided in the battle by Giants such as Cottus, Briareus, and Gyes, the Cyclopes, and the Hundred-handers (Theog. 507-735). Hesiod's account shows strong influence from Eastern myth (Iapetos, for example, 
may be identified with Japheth in Genesis 10.1). The presence of Giants in the Old Testament is clear from the apocryphal Book of Enoch (ed. \& tr. Charles 1913) where they are the children of angels and humans (Enoch 6-11), whose evil-doing brought on the Flood in which all humans except for Noah and his family were drowned. The Jewish and Greek traditions were blended in the Sibylline Oracles-a text that had a strong influence on later Christianity owing to the attention paid to it especially by Lactantius and Augustine, primarily because it predicted the dissolution of Roman power. ${ }^{45}$ Book 1.1-218 of the Sibylline Oracles describes the creation, the Fall, the generation of four ages of men: first, a long-lived race of builders condemned to Hades because of their transgressions against the family and their war-making; second, a race of inventors who discovered how to plough the land, sail the seas, divine the future and control nature through drugs and magic, but were nevertheless eventually sent to Tartaros; third, arrogant murderers; fourth, impious killers, despatched to Erebos. These were followed by the "perverse" Giants (1.153) who were destroyed by the Flood. After them, the sixth race was created: beings who lived in great happiness and ruled by just kings, who fairly distributed rewards to those who work hard and do deeds of love. The earth spontaneously produced corn to feed these people. Their deaths were like falling asleep. They were succeeded by the Titans who fought against heaven. Their rebellion was ended with the final fixing of the seas, harbours, and headlands (1.387-92).46 The more conventional Greek myth of the Titans and their role in suppressing the rule of Zeus is given in the third book of the Sibylline Oracles (153-90). The gigantomachy motif therefore features as a powerful theme in the literature of the alienated and dispossessed under the Roman Empire. ${ }^{47}$

The Gigantomachy theme is also found in the hyper-mannerist Dionysiaca of Nonnos, a fifth-century epic poet from Panoplis in Egypt. This is a loosely structured epic poem written in metrical Greek in forty-eight books, covering the events surrounding the invasion of India by the god Dionysos and his followers, and rivalling the epic poems of Homer. The Dionysiaca concerns the birth of Dionysus from the thigh of Zeus, his gift of wine to mankind, his combat against the Giants, his invasion of India, and his apotheosis (see Dionysiaca 7.73-105, tr. Rouse). Book 1 of Nonnos' poem describes how Typhoeus, a Giant with a hundred heads, two hundred arms, and a body from which snakes extended, stole the "weapons of fire" (1.156), the lightning bolts, from Zeus with the connivance of Ge, the Earth. Typhoeus brings about 
havoc in the cosmos and on earth a full-scale assault on heaven (Books 1-2) before the weapons of Zeus are recovered and the Giant defeated. The battle involves storms, the disruption of nature, and the rending of the earth by the Giant before his end. Typhoeus was buried beneath the island of Sicily (2.620-30). Book 28 (172-276) relates how the Cyclopes (Steropes, Brontes, Trachios, Euryalos and others) ally themselves with Dionysus in his battle against the Indians. They tear off mountain tops and employ wind and storm in their assault before suddently dropping out of the narrative. In Book 48 (lines 1-86) Hera arms her sons, the Giants, with pieces of the earth to fight against Dionysos, but they are ultimately beaten.

There are several reasons why Camões may have been interested in the Dionysiaca. The text of Nonnos' poem was first printed with a Latin translation in 1569 in Antwerp (but of course some manuscripts survived from the fifth century). ${ }^{48}$ It is not known exactly when the Lusiads were written but most of it was written in Europe before his departure and in Macao, where he was a colonial official. Camões himself hints that the poem (o Canto) survived shipwreck at the mouth of the Mekong river in 1559 (10.128), but it is probable that at least the final book of the poem was composed on the poet's return to Lisbon in 1569, the date of the translation of Nonnos into Latin. ${ }^{49}$ The poem was finally printed in 1572. Camões refers to his loss of desire to write in his declining years in Book Ten (10.8: O gosto de escrever que vou perdendo; 10.9: Vão os annos descendo) indicating that he was still engaged in composing the poem in his old age. Thus it is possible that Camões knew of Nonnos' work in the final stages of composition of the Lusiads. The poems share general similarities: both include an extensive mythological framework (although this is much more complex in Nonnos), both describe an expedition to India and conflict with the people there, both narratives include a great deal of sensuality (see the Island of Love in Camões 9.52-88, and the loves of Zeus in Nonnos 1.34451, 48.106-82 [the wrestling match between Dionysos and Pallene], 48.238-947 [the homosexual encounter between Aura and Artemis and the rape of Aura by Dionsysos], for example). Bacchus / Dionysos is a central character in both works. There are differences too, of course, not least the fact that in the Lusiads, Bacchus opposes the Portuguese expedition whereas in Nonnos it is Dionysos who invades India. ${ }^{50}$

The extensive tradition of gigantomachy in Classical literature provides an important perspective from which to understand the Adamastor myth. The erotic interlude with Thetis may have been 
introduced under the influence of Nonnos or Ovid (specifically the Actaeon myth), that nowhere appears in the earlier versions (the blending of the two narratives is quite awkward in Camões). Adamastor's failed love for Thetis casts him into the role of rejected (but violent) lover. In this way he is given a human character for whom the reader can feel sympathy, as in the case of Polyphemus and Galatea. At the same time Thetis was a powerful goddess. ${ }^{51}$ The question therefore arises as to why Camões included this powerful myth in his poem, and secondly, why he represented it in such an unconventional way. The narrative is placed in the central position in the work-a position of great significance in his model Virgil, who places Aeneas' descent into the underworld in the middle of his poem. ${ }^{52}$ The myth is positioned at a key moment in the narrative as the Portuguese sailors venture from Lisbon into the unknown. To some extent the figure of Adamastor personifies the powerful challenges that faced these explorers in their small caravels. But Adamastor's story is more complex than this. It resembles in part that of Prometheus, the god tormented for his friendship with mankind in the remote regions of the inhospitable earth. This theme was popular in the Renaissance, particularly as a trope for the artist-as-creator, and thus for the poet himself. The struggle of the Titans against the gods evokes uncomfortable connotations of the assault on law and authority, civil conflict, incest, familial strife, greed, and the inherent sinfulness of human nature. The negative overtones of the myth was suited to Camões' exilic perspective and oblique critical stance towards Portuguese imperial policy. It is quite in keeping with the social conditions in Lisbon in the final years of the author's life: the obliteration of Portuguese power at the battle of Alcácer-Kebir in 1578, the plague of 1579, and the loss of political influence to Spain after 1580, the year of the poet's death.

\section{Appendix: the Name Adamastor}

The word adamasto:r is not an entirely invented word or name. ${ }^{53} \mathrm{It}$ is found as an epithet of Hekate, the goddess of the underworld, in a Greek magical papyrus (PGM 4.2716 [Preisendanz 1973-1974]). ${ }^{54}$ This is the text of a love spell of attraction. The word in question is translated as "the one untamed" by Betz (1992: 89) as follows:

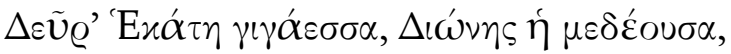

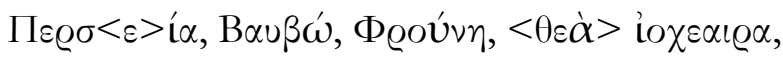

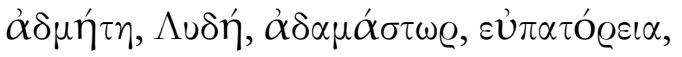




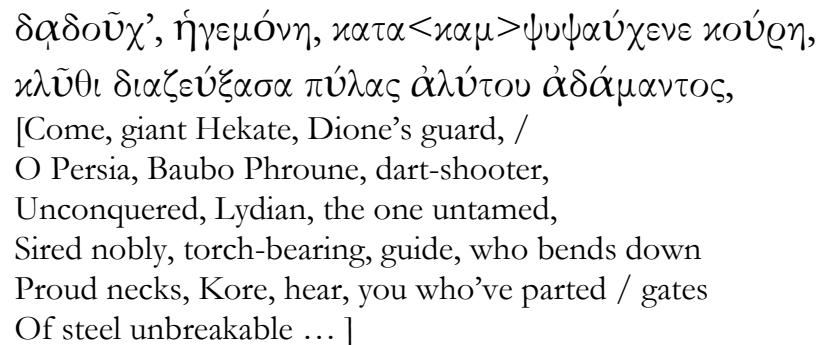

This epithet has a synonym in the same text (adme:te: = "unconquered," see the adjective adamatos "unwedded" in reference to young women in Sophocles' Ajax 450) and its meaning should therefore be fairly clear. ${ }^{55}$ The word is related to the Greek word for an exceptionally hard material (adamas, "adamant"). ${ }^{56}$ Etymologically, however, the derivation of a-damas-to:r from an alpha privative prefix $a$ - ("not"), a base damas ("tame" from the verb damazo:, see Chantraine 1968 ad loc.), and an agent suffix -to:r ("one who ...") is problematic because it is not easy to extract the required passive meaning from it ("the one untamed") since there is no indication that the base carries a passive signification ("tamed") rather than an active one ("tame") and the suffix is clearly active. The -tor suffix is often used as an agent noun in a religious context (see, for example, pantocrator etc.). These nouns proliferated in the Graeco-Roman period under the influence of Latin loan words in -tor, such as balneator "bath attendant," resulting in a number of new words. ${ }^{57}$ The word as we have it should therefore mean "one who does not tame" rather than "one who is not tamed." The passive meaning of "Adamasto:r" may, however, be helped by the related Greek word adamastos "untamed." Apuleius (De Platone et eius Dogmate 191) attributes to Plato the use of this rare adjective as an attribute of the supreme creator (cf. Tim. 28c). In fact, however, Plato does not use this word, 58 which appears rather as an attribute of Hades, the god of the underworld in Homer (Il. 9.158-159) in Agamemon's appeal to Achilles to relent his anger:

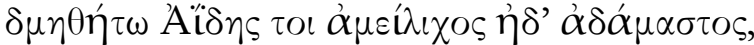

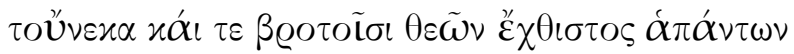

[Let him give way. For Hades gives not way, and is pitiless (adamastos), and therefore he among all the gods is most hateful to mortals] (tr. Lattimore 1951). ${ }^{59}$ 
It is unlikely that Camões had direct knowledge of the magical spell quoted above since the Greek texts describing sorcery were suppressed in antiquity and the magical papyri were only discovered in the nineteenth century. The fragments were only fully edited and translated in the twentieth century. ${ }^{60}$ Nevertheless, the possibility that these texts were transmitted secretly throughout the Middle Ages cannot be excluded entirely. ${ }^{61}$ Certainly, the discovery of ancient books of magic by Jean d'Anastasi in the eighteenth century suggests this (Betz xlii). Magic played a part in the ritual reenactment of the mysteries, particularly the neo-Orphic cults of the fifteenth-century Florentine Neoplatonists Ficino and Pico della Mirandola (Wind 6-7), and the motif of the "tortured Cupid" closely resembles actions prescribed in a magical spell of late antiquity (Wind 146 n. 19). A further indication of the continued transmission of the name is its occurrence as the name of a Giant in François Rabelais' genealogy of Pantagruel in Gargantua and Pantagruel Book 2, Chapter 1.62 Rabelais here uses the names of a number of Giants known from Graeco-Roman and JudaeoChristian literature, such as Atlas, Goliath, Polyphemus, Antaeus, and so on. Since Rabelais' work was published in 1530 or 1534, it would have been well known to Camões who published his Lusiads in 1572. The blending of Jewish and Greek Giant lore is striking in Rabelais' list and it is possible that the name "Adamastor" was thought of as a Semitic / Greek compound of "Adam," a name whose letters represent east (anatole:), west (dusis), north (arktos), and south (mesembria) in Greek (and so the name stands for the earth) and "aste:r" meaning "star." This would be a fitting name for a Giant, since Giants were the sons of Heaven and Earth. Douglas Livingstone in The Sea my Winding Sheet (1964) poetically refers to "Adam Astor." 63

The word "Adamastor" therefore has an unusual form in Greek. The late Latin poet Claudius Claudianus uses the Latinised name "Damastor" of a Giant in his Gigantomachia or "Battle of Giants" (line 100-104). ${ }^{64}$ The etymology of this name is discussed by the Etymologicum Magnum (s.v. "Damasos"). According to this authority the proper name derives from Greek dedamastai in the same way as the proper noun "Telestor" is derived from tetelestai. Unfortunately, this does not help resolve the question of whether the base of "Adamastor" is active or passive, since dedamastai is a medio-passive form "X has tamed / has been tamed" (tetelestai means "X has accomplished / has been accomplished"). Nevertheless, the meaning of "Damastor" would probably be "Tamer" rather than "One who is tamed" since the middle voice is more in keeping with 
the agent function of the suffix -tor. In Claudian's poem the Giants do battle with the Greek gods in defence of their mother, the Earth. During the battle Minerva makes use of the Gorgon's head which turns all who look on it to stone. The Giant Pallas is petrified in this way and his brother Damastor makes use of his lithified body to attack the gods.

\section{vix panca locutus \\ quod timuit, iam totus erat; saevusque Damastor, \\ ad depellendos iaculum cum quaereret hostes, \\ germani rigidum misit pro rupe cadaver.}

[Scarce had he (Pallas) uttered these few words when he was what he feared (i.e. stone), and savage Damastor, seeking a weapon wherewith to repel the foe, hurled at them in place of a rock his brother's stony corpse.] (ed. \& tr. Platnauer).

"Damastor" is also found in Sidonius Apollinaris (Carm. 15.20-a description of the Gigantomachy on the breastplate of Pallas Athena) where one MS records a variant reading "Adamastor." Most editors follow the majority of the MSS and print "Damastor" here, supporting their reading on the basis of Claudian's use of the name. Pierce (1972: 209) suggests that Camões learnt of the name from the work of a French scholar, John Ravisius-Textor who discussed variant spellings of the name in sixteenth-century editions of Claudian in his Officina (1522). ${ }^{65}$ In a Latin context, "Adamastor" is very close to adamator = "lover" (see TLL s.v. "adamator") and to the Latin ear it comes across as a combination of adamastus "hard" and adamator "lover"-an appropriate coinage for the lover of Thetis turned into a rocky promontory by the gods for his rebellion against them.

\section{NOTES}

1 South African writers from Moodie to Brink have made Adamastor the subject of their work. See the compilation by M. Van Wyk Smith, Shades of Adamastor: Africa and the Portuguese Connection (Grahamstown: Institute for the Study of English in Africa, 1988), to which add André Brink, The First Life of Adamastor (London: Vintage, 1993), Anthony Fleischer, Children of Adamastor (Cape Town: David Philip, 1992). Critical studies include S. Gray, Southern African Literature: An Introduction (Cape Town: David Philip, 1979), 15-37; R. Harnett, "Some Poems by Sidney Clouts," English in Africa, 11 (1984): 108161; Sally-Ann Murray, A. E. Voss and Marcia Leveson, "Roy Campbell's Adamastor: Reading and Re-reading the South African 
Poems," in South African English Literature, ed. M. Chapman (Johannesburg: AD Donker, 1992): 94-112; David Quint, "The Epic Curse and Camoes' Adamastor," in Epic and Empire: Politics and Generic Form from Virgil to Milton, ed. D. Quint (Princeton: Princeton University Press, 1993): 99-130; Lawrence Lipking, "The Genius of the Shore: Lycidas, Adamastor, and the Poetics of Nationalism," Publications of the Modern Language Association of America 3 (1996): 205221; Michael Chapman, "Roy Campbell, Poet: A Defence in Sociological Times," Theoria 68 (1986): 79-94; besides the scholarship on Camões, such as Luis Vaz de Camões (tr. W. J. Mickle), The Lusiad or the Discovery of India. An Epic Poem (London: George Bell and Sons, 1889): xv-lxxxv; C. M. Bowra, From Virgil to Milton (London: Macmillan, 1961 [First published in 1945]); Frank Pierce, "The Place of Mythology in the Lusiads," Comparative Literature 6 (1954): 97-122; Frank Pierce, "Camões' Adamastor," in Hispanic Studies in Honour of Joseph Manson, ed. W. C. Atkinson and A. H. Clarke (Oxford: Oxford University Press, 1972): 97-122; and Americo da Costa Ramalho, Estudos Camonianos (Lisboa: Instituto Nacional de Investigacao Cientifica, 1980).

2 According to Mickle (xvi), Camões had "an intimacy with the Classics, equal to that of a Scaliger, but directed by the taste of a Milton or a Pope." See Bowra (87-88), who remarks that he was a Latinist who probably did not know Greek, a claim tentatively supported by Bacon in his translation: Luis Vaz de Camoens (tr. L. Bacon), The Lusiads (New York: The Hispanic Society of America, 1950): xiii, but disputed by Charles E. Nowell, A History of Portugal (Van Nostrand: Princeton, 1952): 122-34. Bowra 124 gives a thorough account of his debt to Classical literature. See also Ramalho (1-26). G. Highet, The Classical Tradition: Greek and Roman Influences on Western Literature (London: Oxford University Press, 1949): 134 notes that Camões translated Plautus' Amphitryo for a production at the University of Coimbra. Bacon (xv) states that Camões wrote a play on the theme of the Hellenistic king Seleucus and the love of his son Antiochus for his stepmother Stratonike, based on a story in Plutarch's Life of Demetrius 38 (the story was also told in Latin by Valerius Maximus 5.7 ext 1, and became a commonplace, cf. Seneca Contr. 6.7). However, it is unthinkable that Greek texts would not be known to university-educated men in the high Renaissance, and Camões refers often to Plutarch as Bacon's notes show. Many Greek texts were in any case translated into Latin at this time.

3 No matter that St. Elmo's fire and waterspouts had in fact been described by ancient writers (see Homeric Hymn 33, Diod. Sic. 4.56.4, Lucretius 6.426-50; Pliny HN 2.101 and later Johannes Lydus De Ostentis / On Signs 5 for the former, Pliny HN 2.134 for the latter). 
What matters is that Da Gama considered them unknown natural phenomena.

4 Not "Pompey" as White translates in Luis Vaz de Camões (tr. L. White), The Lusiads (Oxford: Oxford University Press, 1997), perhaps misled by the fact that the Roman general Pompey had the cognomen Strabo. White also mistranslates Camões' "Tétis" (5.55 and elsewhere) as "Tethys" instead of "Thetis." There was room for confusion (see below n. 9).

5 Compare Camões' treatment of this episode with the famous rejection of the "civilised" gifts of Cambyses' spies by the Ethiopian king in Herodotus (3.20-23) and the topos of barter exchanges where it is not possible to communicate through language (see Hdt. 4.196; Pliny HN 6.188; Cosmas Indicopleustes Christian Topography 2.139).

6 "Ethiopian" is the standard term for Blacks in Greek and Latin literature, see F. M. Snowden, Before Color Prejudice: The Ancient View of Blacks (Cambridge, Mass.: Harvard University Press, 1983): 7; Lloyd Thompson, Romans and Blacks (London: Routledge, 1989): 49-54. The term was originally applied to Indians as well as Africans, and here the explorers clearly do not make the distinction and think that the West Africans may therefore know something of India, the goal of their voyage.

7 Camões does not distinguish between Titans, Giants, and Cyclopses, and consistently uses the term "giant" or a circumlocution as here. All three types were children of Ge and Ouranos. The Titans (see Hes. Theog. 207) were old gods who dwelled in Tartarus and no longer concerned themselves with men, see Hesiod (ed. M. L. West), Theogony (Oxford: Oxford University Press, 1966): 200- they included the Cyclopes, who were Titans who supplied Zeus with his thunderbolts (Hes. Theog. 139), and Hundred-handers (ibid.). The Giants were born of Earth from the blood of Ouranos after he had been castrated by Kronos (Hes. Theog. 185).

8 Enceladus and Briareus-Aegeon were Giants, not Titans. Enceladus was thought to be a Giant buried under Mt. Etna in Sicily (Aen. 3.578; Claudian De Rapt. Pros. 1.154). Briareus was a Giant with 100 hands and 50 heads. He was called Briareus by gods, Aegeon by men (Hom. Il. 1.403-404). These Giants do not occur together in any single work to my knowledge, and so Camões is making a rather imprecise allusion to them here.

9 Doris was the daughter of Oceanus and Tethys, the wife of Nereus, and the mother of the Nereids. Virgil (Ecl. 10.5) uses her name as a metonym for the sea, in the same way that he employs Thetis (Ecl. 4.32). Hesiod (Theog. 241-264) lists the 50 daughters of Nereus and Doris, including Thetis (Theog. 244).

10 See also Voltaire, An Essay on Epick Poetry (London: 1727), who judged the episode "noble and proper" quoted by Mickle (xxv), see 
also Mickle (146 n. 1) Adamastor "stands unsurpassed in human composition"; Bacon (204); Pierce (“Camões’ Adamastor” 205-215); Lipking (214); Chapman (76), "the Adamastor encounter remains very much a white man's creation myth of agonised self-appraisal." The link between Adamastor and the French Revolution is made in Chapter 7 of Herman Melville's Billy Budd (see Quint 384, n. 37).

11 See R. Brasil in his commentary on the poem, Luís Vaz de Camões (ed. R. Brasil), Os Lusíadas: Comentários e estudo critico. 7 v. (Lisbon: 1960-1969): 5.171-296, referred to by Pierce (“Camões’ Adamastor" 210, n. 5). Bacon (xvii) attributes the invention of Adamastor to Rabelais.

12 Previous studies of the Classical intertexts with the Adamastor passage include Américo da Costa Ramalho (33-53) and the quirky observations of Bacon ad loc.

13 For gigantomachy myths, see Philip Hardie, Virgil's Aeneid: Cosmos and Imperium (Oxford: Clarendon Press, 1986): 85; for treatment of this theme in recusatio poems see D. C. Innes, "Gigantomachy and Natural Philosophy," Classical Quarterly 29 (1979): 165-171 at 165.

14 The recusatio in $A m$. 2.11-16 may be a back-handed comment by Ovid, implying that the myth (and Augustus) was somewhat overdone already and dull and too boring a subject to entertain his mistress with. Elsewhere Ovid suggests that "Jupiter" (i.e. Augustus) might have been quite pleased by the story (Trist. 2.1.71-72), and certainly Virgil did not avoid it. It is uncertain whether Ovid did compose a poem on this theme, see Green in Ovid (tr. P. Green), The Poems of Exile (Harmondsworth / London: Penguin, 1994): 224.

15 On pagan mysteries and their associated myths in the Renaissance, see Edgar Wind, Pagan Mysteries in the Renaissance (Oxford: Oxford University Press, 1980).

16 For the paradox of Aeschylus' treatment of the myth in his Prometheus Vinctus, see Lewis R. Farnell, "The Paradox of the Prometheus Vinctus," JHS 53 (1933): 40-50.

17 Olga Raggio, "The Myth of Prometheus," Journal of the Warburg Institute 21 (1958): 44-62.

18 Pierce ("The Place of Mythology" 98). See also the criticism of Voltaire: "there is another kind of machinery continued throughout all the poem, which nothing can excuse; that is, an injudicious mixture of the heathen gods with our religion." Quoted by Mickle (xxvi).

19 On exile literature in the Classical period, see Jo-Marie Claassen, Displaced Persons: The Literature of Exile from Cicero to Boethius (London: Duckworth, 1999): 252-258. The attitude of a person forced into exile towards his native land varies from adulation to invective resulting in a number of personae. 
20 Atkinson in Luis Vaz de Camoens (tr. W. C. Atkinson), The Lusiads (Harmondsworth: Penguin, 1952): 7.

21 Valerius Maximus (5.3.2b) records the epitaph as ingrata patra, ne ossa quidem mea habes, "Ungrateful fatherland, you do not have even my bones." Livy 38.53.8 records Scipio's wish that he be buried outside Rome at Liternum because of the ingratitude of his fellow citizens.

22 For the importance of guest-friendship in the story, see A. J. Podlecki, "Guest Gifts and Nobodies in Odyssey 9," Phoenix 15 (1961): 125-133.

23 For the opposition between nature and culture in the Polyphemus story, see G. S. Kirk, Myth: Its Meaning and Functions in Ancient and Other Cultures (Cambridge: Cambridge University Press, 1970): 162171. Cyclopic Giants are known from much earlier Mesopotamian myth: see Mary Knox, "Polyphemos and his Near Eastern Relations," JHS 99 (1979): 164-165. Variants of the tale are found in the mythologies of many nations, see J. Glenn, "The Polyphemus Folktale and Homer's Kykloppeia," Transactions of the American Philological Association 102 (1971): 133-81 and the literature cited there.

24 See the translation of N. J. Dawood, Tales from the Thousand and One Nights (Harmondsworth: Penguin, 1973): 128-135.

25 Camões' description of Adamastor assimilates the Giant with the earth (Cheios de terra), but at the same time characterises him as negroid (crespos os cabellos): De disforme e grandissima estatura, / O rosto carregado, a barba esqualida, / Os olhos encovados, e a postura / Medonha e má, e a côr terrena e pallida, / Cheios de terra e crespos os cabellos, / A bôca negra, os dentes amarellos, "Of stature all deformed and vast and tall, / The visage frowning, and with squalid beard; / The eyes were hollow, and the gesture all / Threatening and bad; the colour pale and seared; / And full of earth and grizzly was the hair; / The mouth was black, the teeth all yellow were." (5.39, tr. Aubertin).

26 Glenn (147-149).

27 For the way Homer introduces elements into his narrative, such as Polyphemus' affection for his ram, that will make the reader sympathetic to the Giant, see Rick Newton, "Poor Polyphemus: Emotional Ambivalence in Odyssey 9 and 17," Classical World 76.3 (1983): 137-142. For the psychoanalytic interpretation, see Justin Glenn, "The Polyphemus Myth: Its Origin and Interpretation," Greece \& Rome 25 (1978): 141-155.

28 Water seeping from a rock was an ancient metaphor for desire (Hesychius s.v. "lips," see liptomai) and Ovid's text here achieves a moment of rare sublime pathos.

29 S. Rautenbach, "Cyclopes (I)," Acta Classica 27 (1984): 41-55, at 51, adds further details of the benevolent aspect of Cyclopes.

30 Theocritus (ed. A. S. F. Gow), Theocritus: Edited with a Translation and Commentary (Cambridge: Cambridge University Press, 1965): 2.118, 
Alan H. F. Griffin, "Unrequited Love: Polyphemus and Galatea in Ovid's Metamorphoses," Greece \& Rome 30.2 (1983): 190-97, at 191.

31 The name is known from Roman inscriptions, cf. CIL 6.24200. It appears to be a Latinised form of the Greek adamastos, "untamed" and should not be confused with adamatus, "beloved."

32 Justin Glenn, "Virgil's Polyphemus," Greece \& Rome 19.1 (1972): 4759 , at 59. The myth would have had a special resonance for Camões, who lost an eye fighting in Morocco (Nowell 126), and was himself in some sense Cyclopic.

33 This is the "I see the Tiber foaming with blood" speech (Thybrim multo spumantem sanguine cerno 6.87) invoked by Enoch Powell in his 1968 address at Birmingham on the issue of immigration into Britain.

34 Michael Chapman, Southern African Literatures (Pietermaritzburg: University of Natal Press, 2003): 76, states that the curse of Adamastor "has taken on increasingly menacing proportions and has echoed through the literature and history of European conquest and settlement on the subcontinent."

35 The idea of transgressing forbidden realms is an extension of the idea that mankind sinned by venturing into domains beyond those allowed by nature. Horace Odes 1.3 links this idea, which includes the act of seafaring itself, to the fault of Prometheus in stealing fire from the gods.

36 For Prometheus' use of this prophecy in securing his liberation, see C. Kerényi (tr. R. Mannheim), Prometheus: Archetypal Image of Human Existence (London: Thames \& Hudson, 1963); George Thomson, "Prometheia," in Aeschylus: A Collection of Critical Essays, ed. M. H. McCall (Englewood Cliffs: Prentice-Hall, 1972): 124-147, gives an excellent account of the ideological use of the Prometheus myth in the later tradition.

37 Da Gama concedes that the land they are passing by is possessed by the native inhabitants (5.62). Chapman (Southern African Literatures 76) characterises (in my view wrongly) Mickle's depiction of Adamastor as "a vast and ominous spirit of a continent resisting the imperial mission" but also talks of the encounter as an "agonised selfappraisal" in which motifs of "challenge and defiance, possession and dispossession, belonging and alienation" are clustered (in my view correctly).

38 See Quint 124, "the African natives have indeed disappeared for readers of the poem."

39 According to Lipking (217), Adamastor's portentous existence glorifies the achievement of the Portuguese explorers. For Bowra (125) Adamastor is an abstraction-a symbol of the difficulties the Portuguese ships experienced in rounding the Cape.

40 For gigantomachies in Classical mythology, see F. Vian and M. B. Moore, "Gigantes," in Lexicon Iconographicum Mythologiae Classicae, ed. 
H. C. Ackermann and J.-R. Gisler (Zurich and Munich: Artemis, 1988): 191-270.

41 See Pierce ("Camões' Adamastor" 209); Bowra (123); Balthasar Osorio, "Origens do episódio dos Lusíadas: O gigante Adamastor," Academia das Ciências de Lisboa, Boletim da Segunda Classe 4 (1910): 521526.

42 On the interpretation of the Cyclopes as a mythological reflex of volcanoes, see Rautenbach (43). Alwyn Scarth, "Volcanic Origins of the Polyphemus Story in the Odyssey: a Non-classicist's Interpretation," Classical World 83 (1989-1990): 89-95, argues that the Polyphemus episode as a whole reflects volcanic activity and should be specifically located on Mt. Etna. For a more sceptical point of view, see Glenn “The Polyphemus Myth"141-155.

43 On the eastern origin of the Prometheus myth, see S. West, "Prometheus Orientalized," Museum Helveticum 51 (1994): 129-49.

44 The importance of the Gigantomachy myth in ancient thought is clear from the sculptural representations of the story on many ancient temples, particularly the marble frieze on Great Altar of the temple of Zeus at Pergamum. For these see Vian and Moore (191270). For discussion of Prometheus as "the patron saint of the proletariat), see Thomson (124-47 at p. 124).

45 Jane L. Lightfoot, "Giants and Titans in Oracula Sibyllina 1-2," in Des Géants à Dionysos: Mélanges de mythologie et de poésie grecques offerts à Francis Vian, ed. D. C. Accorinti (Allessandria: 2003): 393-401, at 400; B. C. McGing (ed.) Parke Herbert William: Sibyls and Sibylline Prophecy in Classical Antiquity (London: Routledge, 1988).

46 The appeal of this scheme of successive races is evident from its recurrence in the work of the nineteenth-century spiritualist, Madame Blavatsky: H. P. Blavatsky, Isis Unveiled (London: Theosophical Publishing House, 1877); H. P. Blavatsky, The Secret Doctrine (London: Theosophical Publishing House, 1884).

47 R. MacMullen, Enemies of the Roman Order: Treason Unrest and Alienation in the Empire (Cambridge, Mass.: Harvard University Press, 1966).

48 Nonnus (ed. W. H. D. Rouse), Dionysiaca. Three Volumes (Cambridge, Mass. and London: Heinemann, 1962): 1.xliii.

49 Bacon (32, note on 1.32) discounts the possibility that Camões knew Nonnos, but without substantial cause, in my view.

50 The loyalties of Bacchus do appear changeable, however. In Roman literature he deserts Antony for his enemy, Octavian. See John A. Stevens, "Seneca and Horace," Phoenix 53.3-4 (1999): 281-307.

51 Laura Slatkin, The Power of Thetis: Allusion and Interpretation in the Iliad (Berkeley, Los Angeles, \& London: University of Chicago Press, 1991).

52 For the central position of the Adamastor episode, see Pierce (“Camões' Adamastor” 207). 
53 See Bacon 205-206.

54 However, see also adamato:r also used of Hekate in P.Mag.Par. 1.2717 .

55 "Admetos" is a fairly common Greek name meaning "untamed," see the Homeric adamatos "unbroken" (of animals), "unwedded" (of women).

56 See TLL s.v. "Adamas."

57 See the discussion in L.R. Palmer, A Grammar of the Post-Ptolemaic Papyri. Vol. I Accidence and Word-formation. Part I: Suffixes (Oxford: Oxford University Press, 1946): 118-119.

58 According to Beaujeu in Apulée, Opuscules philosophiques et fragments, ed. J. Beaujeu (Paris: Les Belles Lettres, 1973): 257, Apuleius might have had in mind the epithet adrasteia "the inevitable" used of Nemesis in Plato's Phaedrus (248c).

59 "Adamastos" also occurs as a proper noun in a Greek inscription (IG IX.1(2) 1-3).

60 H. D. Betz (ed.) The Greek Magical Papyri in Translation including the Demotic Spells (Chicago: University of Chicago Press, 1992).

61 A. A. Barb, "The Survival of Magic Arts," in The Conflict between Paganism and Christianity in the Fourth Century, ed. A. Momigliano (Oxford: Oxford University Press, 1963): 100-125.

62 Francois Rabelais (tr. J. M. Cohen), The Histories of Gargantua and Pantagruel (London: Penguin, 1955): 173.

63 Douglas Livingstone, “Adamastor Resuscitated' from The Sea My Winding Sheet: A Radio Play," in Theatre One: New South African Drama, ed. S. Gray (Johannesburg: A. D. Donker, 1978). It is curious incidentally that the name Adamastor comes very close to fulfilling the name-riddle posed by the Creator in the Sibylline Oracles (1.17581). The conundrum specifies a name of nine letters, four syllables, five consonants. The first three syllables have two letters each, and the total of all the letters is 1697. Of these conditions, the name Adamastor fails only the last (the total represented by the name is 1447). No other name has been put forward that satisfies this problem and editors suspect an error in the text. See Milton S. Terry (tr.), The Sibylline Oracles (New York: Eaton \& Mains, 1899): ad loc. The interest of the Sibylline oracles in such onomastic puzzles is evident in the famous Christian acrostic ixthus (8.284-330).

64 On the name see Ramalho (27-34). "Damastes" is also attested as a name. Fragments of the writings of a fifth-century geographer and historian by this name survive.

65 It is clear that Camões had a good knowledge of Claudian's poetry. Some examples of passages that are similar in the two poets are: 1.23 $=$ De Raptu Proserpinae 3.8 (the seating order of the gods); $1.46=D e$ III cons. Hon. 122-25 (the sister/s of Phaethon); $2.21=$ De Nuptiis Hon. 128-30 (Triton carrying Venus on his shoulders). 


\section{NOTES ON CONTRIBUTORS}

John L. Hilton is Professor of Classics at the University of KwaZulu-Natal, Howard College, Durban, South Africa. His publications include Alma Parens Originalis: The Receptions of Classical Literature and Thought in Africa, Europe, the United States, and Cuba (2007); Apuleius: Rhetorical Works (co-tr.) (2001), An Introduction to Latin 1-4 (1990-91), and numerous chapters and articles on various topics, including Heliodorus, Azania and Latin linguistics. Forthcoming is A Commentary on Books 3 and 4 of Leucippe and Clitophon by Acbilles Tatius. He is a past Chairperson of the Classical Association of South Africa, is a member of the Advisory Board of Acta Classia, and has been reviews editor of the international classics journal Scholia and editor of the electronic reviews journal Scholia Reviews since 1991.

Stephen Kolsky is an Honorary Professorial Fellow at the University of Melbourne, where he taught Italian for many years. His main interests are in medieval and renaissance studies, in particular Renaissance theories of behaviour, especially Castiglione and Della Casa. Recently, his research has concentrated on theories of gender in the early modern period. His most recent book, The Ghost of Boccaccio. Writings on Famous Women in Renaissance Italy, was published in 2005. He is also an active researcher in the field of 20th century Italian literature, especially drama and narrative.

Stéphane Natan is an assistant professor of French at Rider University, New Jersey. His field of study covers seventeenthcentury French literature. Passionate about Pascal, he has published a number of articles in journals in different countries (France, Belgium, Canada, the United Kingdom, and the United States). In 2005, his book, Les Pensées de Pascal: D'un projet apologétique à un texte poétique (Paris: Connaissances et Savoirs), was published. 
Reproduced with permission of the copyright owner. Further reproduction prohibited without permission. 